Revista Eletrônica Geografar, Curitiba, v. 2, Resumos do VI Seminário Interno de Pós-Graduação em Geografia, p. 45-45. Junho/2007

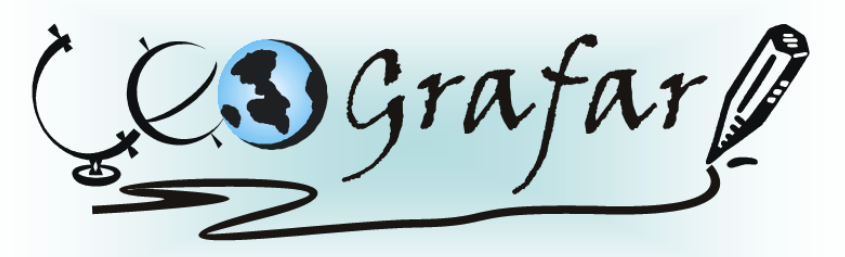

Revista Eletrônica do Programa de Pós-Graduação em Geografia - UFPR

\title{
ACIDENTES LOXOSCÉLICOS EM CURITBA/PR: A INFLUÊNCIA DOS FATORES SÓCIOAMBIENTAIS
}

\author{
LEANDRO RAFAEL PINTO ${ }^{1}$
}

A cada dia as relações entre ambiente e sociedade trazem novas descobertas. Atualmente, sabe-se que para estudar todo o complexo que envolve uma doença, que afeta a um grupo social, faz-se necessário um aprofundamento em toda a cadeia que envolve esta relação, ou seja, no âmbito dos fatores ambientais, biológicos, sociais, econômicos, dentre outros, da enfermidade envolvida. O presente estudo visará analisar a influência dos fatores sociais e ambientais na distribuição sazonal e espacial dos casos de acidentes Loxoscélicos (ataques pela popularmente conhecida "aranha-marrom") em Curitiba/PR, tomando como base desde os primeiros ataques na década de 80 e também o crescimento urbano da cidade e a própria evolução das temperaturas. A metodologia utilizada será baseada na concepção de multicausalidade (abordagem sistêmica), em que preconiza que a doença não é conseqüência exclusiva da ação de um único agente, mas que fatores interagem para que ela se manifeste. Qualquer ruptura do sistema composto pelo agente, o homem e o ambiente, ou sua desestabilização, geraria um estado de doença. Um dos principais motivos se deve ao fato de que desde o final da década de 80, a cidade de Curitiba vem registrando ano a ano um elevado número de acidentes por animais peçonhentos, mais especialmente acidentes por aranhas do gênero Loxosceles, até o início de dezembro de 2006 a Secretaria municipal de Saúde de Curitiba já havia notificado 1768 casos naquele ano. Diante disto, um trabalho desenvolvido no campo da Geografia da Saúde passa a exercer importante papel, tanto para a busca de elementos que auxiliem no entendimento da espacialidade desta enfermidade em diferentes escalas, bem como para a compreensão da correlação ente sociedade, clima e saúde, mais especificamente da correlação entre os elementos sócio-ambientais preponderantes para a maturação do ambiente de risco e os acidentes Loxoscélicos em Curitiba/PR.

Palavras-chave: Curitiba/PR, Aranha-Marrom, Fatores Sócioambientais.

${ }^{1}$ Mestrando em Geografia - UFPR - email: leandro_geo@pop.com.br Orientador: FRANCISCO DE ASSIS MENDONÇA 